\title{
Extreme rainfall events can alter inter-annual biomass responses to water and $\mathbf{N}$ enrichment
}

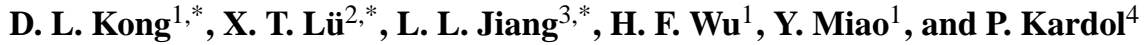 \\ ${ }^{1}$ State Key Laboratory of Cotton Biology, College of Life Sciences, Henan University, Kaifeng 475004, China \\ ${ }^{2}$ State Key Laboratory of Forest and Soil Ecology, Institute of Applied Ecology, Chinese Academy of Sciences, 110016, \\ Shenyang, China \\ ${ }^{3}$ Institute of Tibetan Plateau Research, Chinese Academy of Sciences, 100101, Beijing, China \\ ${ }^{4}$ Department of Forest Ecology and Management, Swedish University of Agricultural Sciences, 90183, Umeå, Sweden \\ *These authors contributed equally to this work.
}

Correspondence to: D. L. Kong (deliangkong1999@126.com)

Received: 13 June 2013 - Published in Biogeosciences Discuss.: 13 August 2013

Revised: 24 October 2013 - Accepted: 11 November 2013 - Published: 11 December 2013

\begin{abstract}
Water availability has profound effects on plant growth and productivity in temperate and semiarid grasslands. However, it remains unclear how variation of interannual precipitation by extreme rainfall events will alter the aboveground and belowground responses of plants, and how these responses may be contingent on $\mathrm{N}$ availability. In this study, we examined the interactive effects of inter-annual precipitation variation and $\mathrm{N}$ addition on aboveground and live fine root biomass of a semiarid grassland in northern China for two consecutive years (2007 and 2008). Interannual variation in precipitation resulting mainly from the occurrence of extreme rainfall events in 2008 significantly affected above- and belowground plant biomass responses to water addition. In addition, variation of inter-annual precipitation by this extreme rainfall event suppressed plant responses to nitrogen addition and reduced the interaction effects between water and nitrogen addition. These effects of inter-annual precipitation fluctuation could be attributed to the negative influence of the extreme rainfall event on soil $\mathrm{N}$ and water availability, ultimately reducing plant rainfall use efficiency and nitrogen use efficiency. In conclusion, our results suggest ecosystem responses to water and $\mathrm{N}$ enrichment could be altered by inter-annual variation of precipitation regime caused by the naturally occurring extreme rainfall events.
\end{abstract}

\section{Introduction}

Plant growth and productivity in semiarid grasslands are highly sensitive to inter-annual changes in water availability (Knapp and Smith, 2001; Bai et al., 2004; Huxman et al., 2004a; Kong et al., 2010; Wu et al., 2011; Hus et al., 2012). With increasing water availability (e.g, in wetter years), plant growth may shift from water limitation to nutrient limitation and hence be more sensitive to nitrogen $(\mathrm{N})$ than to water addition (Hooper and Johnson, 1999; Xiao et al., 2007; Xia and Wan, 2008). This may be due to release from water limitation in wetter years (LeBauer and Treseder, 2008). Moreover, soil $\mathrm{N}$ may be more available for plants in wetter years because of higher soil mineralization and mobility of inorganic N (Hooper and Johnson, 1999; Wang et al., 2006). These response patterns have been widely demonstrated in semiarid grasslands, but may vary considerably across geographic regions, as for example has been shown for the percentage change in plant biomass and productivity under water or N enrichment (Hooper and Johnson, 1999; Chen and Wang, 2000; LeBauer and Treseder, 2008; Xia and Wan, 2008, Robinson et al., 2013). Uncovering mechanisms underlying variation of plant responses can provide new insights into how ecosystems respond to concurrent multiple global environmental changes (Dukes et al., 2005; Bradford et al., 2012; Kardol et al., 2012). 
Inter-annual variation in the precipitation regime is of the key factors contributing to variation in plant responses to water and $\mathrm{N}$ enrichment within and among sites. Precipitation regime includes many aspects of rainfall events, e.g., total amount of the precipitation, intensity, interval and timing of rainfall events, etc. (Maestre and Reynolds 2007; Fay et al., 2008; Craine et al., 2012; Robinson et al., 2013). Changes in each of these components of the precipitation regime can have a different impact on soil moisture, nutrients and microbe and, hence, can lead to different response patterns of plant growth and ecosystem processes (Weltzin et al., 2003; Huxman et al., 2004b; Fay et al., 2008). Extreme rainfall events are predicted to increase under future climate scenario (Easterling et al., 2000; Knapp et al., 2002; Weltzin et al., 2003; Austin et al., 2004; Zhang et al., 2007; Knapp et al., 2008). Extreme rainfall events can increase ecosystem carbon sequestration (Huxman et al., 2004b; Chen et al., 2009), whereas increasing the interval between these events can reduce plant photosynthesis and soil respiration (Knapp et al., 2002; Fay et al., 2008). Given the close links between carbon and water cycling (Chapin et al., 2002; Huntington, 2006), changes in carbon cycling resulting from increased frequency of extreme rainfall events may in turn feed back to precipitation regime and plant growth. However, we know little about how the occurrence of extreme rainfall events affects plant growth and productivity under conditions of water and $\mathrm{N}$ enrichment.

An important consequence of extreme rainfall events is the potential of surface runoff or leaching (Chapin et al., 2002; Zhou et al., 2008), which can reduce rainfall use efficiency (RUE) as water input from extreme rainfall events may be lost from the system rather than taken up by plants for biomass production. Reduced RUE can also result from decreased soil nutrient availability because of nutrient loss via runoff or leaching. The negative effects of extreme rainfall events on soil available nutrients and hence on RUE can eventually reduce plant responses to water addition. So far, most studies on the impacts of extreme rainfall events on plant productivity have focused on soil water content or its variability (Knapp et al., 2002; Fay et al., 2008; Chen et al., 2009), while few studies have considered the role of changes in soil $\mathrm{N}$ availability. In addition, runoff and leaching by extreme rainfall events will reduce $\mathrm{N}$ use efficiency (NUE) if surplus water cannot be used for improving photosynthetic efficiency at a given N supply rate (Patterson et al., 1997; Zhang and Cao, 2009). Hence, plant growth responses to extreme rainfall events can be mediated through effects both on RUE and NUE. Importantly, shifts in RUE and NUE suggest that extreme rainfall can alter the interaction effects between water and $\mathrm{N}$ addition. For example, soil microbes, which are responsible for soil $\mathrm{N}$ nitrification, are most active under high soil moisture conditions (Chapin et al., 2002; Wang et al., 2006; Liu et al., 2009). In the case of extreme rainfall, combined addition of water and $\mathrm{N}$ may result in the loss of added $\mathrm{N}$ as mobile $\mathrm{NO}_{3}-\mathrm{N}$ leachate. Taken together, extreme rain- fall events can represent an important source of variation in plant responses to water and $\mathrm{N}$ enrichment.

Most studies on the effects of extreme rainfall events are conducted by empirically manipulating individual rainfall event size (e.g., Knapp et al., 2002; Fay et al., 2008; Chen et al., 2009). However, few studies have concentrated on naturally occurring extreme rainfall events and evaluated their influences on plant responses to multiple environmental changes. In this study, we examined the response of aboveground and fine root biomass to water and $\mathrm{N}$ addition in two consecutive years $(2007,2008)$ with highly contrasting precipitation regimes. Annual precipitation was $50 \%$ higher in 2008 than in 2007. However, the majority of the inter-annual variation in precipitation resulted from a single extreme rainfall event in 2008. We tested the following hypotheses. A single extreme rainfall event could (1) reduce above- and belowground plant growth responses to water addition, (2) reduce plant responses to $\mathrm{N}$ addition, and (3) reduce interaction effects of water and $\mathrm{N}$ addition on plant growth responses.

\section{Materials and methods}

\subsection{Study site}

This study was conducted in semiarid grassland of the Eurasian steppe near the Inner Mongolia Grassland Ecosystem Research Station of the Chinese Academy of Sciences $\left(116^{\circ} 42^{\prime} \mathrm{E}, 43^{\circ} 38^{\prime} \mathrm{N}\right)$ with an altitude of $1187 \mathrm{~m}$. The site has been fenced to exclude grazing from large animals since 1999. Before enclosure, it was representative of undisturbed, climax steppe communities (Chen and Wang, 2000; Bai et al., 2004). The dominant plant species at this site are Stipa grandis P. Smirn., Agropyron cristatum (L.) Gaertn., Achnatherum sibiricum (Linn.) Keng and Cleistogenes squarrosa (Trin.) Keng. Long-term mean annual precipitation is approximately $345 \mathrm{~mm}$, most of which falls from June to August. Long-term mean annual temperature is $0.3^{\circ} \mathrm{C}$, and the lowest and highest mean monthly temperature occurs in January and July, respectively (Chen and Wang, 2000). The soil total $\mathrm{N}$ is $2.28 \mathrm{~g} \mathrm{~kg}^{-1}$, and soil $\mathrm{pH}$ is 7.39 before the experiment. The soil is classified as Calcis-orthic Aridisol according to US Soil Taxonomy.

\subsection{Experimental design}

In 20 May 2007, $4 \times 4 \mathrm{~m}$ plots were established. Plots were separated by $1 \mathrm{~m}$ buffer rows. Four treatments (control, C; $\mathrm{N}$ addition, $+\mathrm{N}$; water addition, $+\mathrm{W}$; nitrogen and water addition, $+\mathrm{NW}$ ) were applied in a randomized block design $(N=5)$. Nitrogen was applied as urea (in dry form) in both mid-May and early July in 2007 and 2008, respectively. In total, $\mathrm{N}$ addition plots received $17.5 \mathrm{~g} \mathrm{~N} \mathrm{~m}^{-2}$ per year. It has been reported that $\mathrm{N}$ added at this rate can be used by plants with high efficiency (Kong et al., 2010). Water corresponding to $10 \mathrm{~mm}$ precipitation was added weekly from May to 
September in both 2007 and 2008. To reduce loss from evaporation, water treatments were always applied after 16:00 LT. In total, water addition plots received $180 \mathrm{~mm}$ water per year.

\subsection{Field sampling and measurements}

In 2007 and 2008, shoot biomass was sampled on the 15th day each month from June to September (the growing season) by clipping all plants level to the soil surface in one $1 \mathrm{~m} \times 1 \mathrm{~m}$ quadrat per plot. Aboveground biomass was ovendried at $60^{\circ} \mathrm{C}$ to a constant mass, and weighed. At the time of clipping, in each quadrat, two soil samples $(6 \mathrm{~cm}$ diameter, $20 \mathrm{~cm}$ in depth) were collected. For each plot, the two soil samples were mixed and bulked. Fine roots (diameter $<2 \mathrm{~mm}$ ) were carefully picked from the soil, and rinsed with tap water. Live fine roots were separated from dead roots based on root color and flexibility (Kong et al., 2010), and dead roots were discarded. We concentrated on live fine roots rather than total root biomass because live fine roots are most important for plant water and nutrient uptake and have been shown to be highly sensitive to environmental changes (e.g., Neatrour et al., 2005). The live fine roots were ovendried at $60^{\circ} \mathrm{C}$ to a constant mass, weighed, and then ground to fine powder using a ball mill (Retsch MM 400; Retsch, Haan, Germany). A subsample of ground roots was used to determine $\mathrm{N}$ concentration using a semi-autoanalyzer (Kjeltec 2300 Analyzer Unit, Foss Tecator, Sweden).

To measure soil moisture and soil inorganic $\mathrm{N}$ concentration (sum of $\mathrm{NH}_{4}^{+}-\mathrm{N}$ and $\mathrm{NO}_{3}^{-}-\mathrm{N}$ ), two additional soil samples $(5 \mathrm{~cm}$ diameter, $10 \mathrm{~cm}$ depth) were collected close to where the soil samples for root analyses were collected. Again, for each plot, the two soil samples were mixed and bulked. Then, these soil samples were sieved through a $1 \mathrm{~mm}$ mesh. The sieved soils were extracted with $2.0 \mathrm{M} \mathrm{KCl}$ solution and filtered to determine $\mathrm{NH}_{4}^{+}-\mathrm{N}$ and $\mathrm{NO}_{3}^{-}-\mathrm{N}$ concentration using a continuous flow spectrophotometer (FIAstar 5000, Foss Tecator, Denmark). Mass-based soil moisture (\%) was determined as $\left(m_{\mathrm{i}}-m_{\mathrm{o}}\right) \times 100 / m_{\mathrm{o}}$, where $m_{\mathrm{i}}$ and $m_{\mathrm{o}}$ were the initial and oven-dried (at $105^{\circ} \mathrm{C}$ for $24 \mathrm{~h}$ in aluminum box) soil weight, respectively.

\subsection{Data analysis}

We tested effects of $\mathrm{N}$ and water addition, and their interaction on shoot biomass and live fine root biomass, using two-way repeated measures analysis of variance (ANOVA). These analyses were run separately for 2007 and 2008. Block was used as a random factor. Within months, treatment effects were analyzed using two-way ANOVAs with $\mathrm{N}$ and water addition as fixed factors. Main treatment effects for water addition were calculated as $100 \times(\mathrm{W}-\mathrm{C}+\mathrm{NW}-\mathrm{N}) /(\mathrm{C}+\mathrm{N})$ and for nitrogen addition as $100 \times(\mathrm{N}-\mathrm{C}+\mathrm{NW}-\mathrm{W}) /(\mathrm{C}+\mathrm{W})$, where $\mathrm{C}, \mathrm{N}, \mathrm{W}$, and $\mathrm{NW}$ refer to control, nitrogen addition, water addition, and nitrogen + water addition, respectively. In addition, to examine treatment effect on plant biomass over the two years, two-way repeated measures ANOVA was run for shoot biomass and live fine root biomass, respectively, each with biomass averaged across the four sampling dates per year. Pearson's correlations were used to analyze relationships between plant biomass and soil water content and between plant biomass and soil inorganic N. All analyses were conducted using SPSS 12.0 (SPSS Inc., Chicago, USA). The significant level was set at 0.05 .

In addition, we analyzed effects of "accumulated precipitation" (i.e., the sum of water from both irrigation and rainfall events accumulated over the beginning of a year up to the sampling date). To evaluate the influence of variation in interannual precipitation regime on plant responses, we compared the slopes of regressions of aboveground biomass and live fine root biomass with accumulated precipitation in each year. We used the slope of the regression between aboveground plant biomass and accumulated precipitation as rainfall use efficiency (RUE). In addition, we also analyzed the relationship between live fine root $\mathrm{N}$ uptake and aboveground biomass. Live fine root $\mathrm{N}$ uptake was calculated as the product between live fine root biomass and root $\mathrm{N}$ concentration. There is a strong correlation between roots and shoots in both biomass and $\mathrm{N}$ concentration (Kong et al., 2010; Yang et al., 2010); therefore, we used the slope of the regression between aboveground plant biomass and root $\mathrm{N}$ uptake as a proxy for plant $\mathrm{N}$ use efficiency (NUE). Between-year differences in slopes were analyzed by standardized major axis (SMA) using SMART version 2.0 (Falster et al., 2006). We tested the fit of both linear and polynomial regressions. For 2008, the relationship between aboveground biomass and accumulated precipitation, and the relationship between root $\mathrm{N}$ uptake and accumulated precipitation were better fitted by a quadratic polynomial than by a linear regression.

\section{Results}

\subsection{Precipitation regime}

Total precipitation during the growing season (mid-May to mid-September) was $168.5 \mathrm{~mm}$ and $290.1 \mathrm{~mm}$ in 2007 and 2008, respectively. The higher precipitation in 2008 relative to 2007 mainly fell between the sampling dates in July and August (Fig. 1a).

During this period $142.6 \mathrm{~mm}$ of precipitation fell in 2008 (including a single extreme rainfall event of $63 \mathrm{~mm}$ on 31 July), compared to only $43.3 \mathrm{~mm}$ in 2007. During this period, the precipitation frequency was similar for 2007 and 2008 (intervals about 2.5 days, Fig. $1 \mathrm{~b}$ and c). However, the average amount per precipitation event was much higher in 2008 than in 2007 ( $11.9 \mathrm{~mm}$ vs. $3.3 \mathrm{~mm}$, Fig. $1 \mathrm{~b}$ and c), which was due mainly to the extreme rainfall event in 2008 (Fig. 1c). 


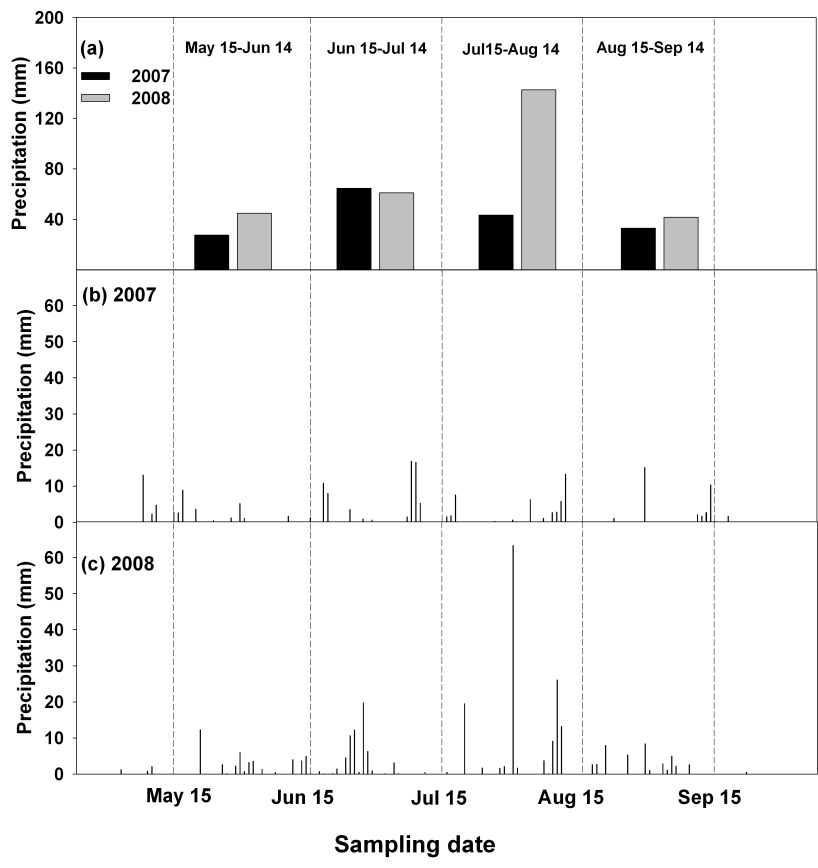

Fig. 1. Monthly (a) and daily precipitation during the growing season in 2007 (b) and 2008 (c). Dashed lines indicate sampling dates.

\subsection{Aboveground biomass}

Aboveground biomass peaked in August of 2007 and 2008 (Fig. 2). In both years, aboveground biomass was significantly increased by water addition (Fig. 2; Table 1). Averaged across the four sampling dates, water addition stimulated biomass equally in $2007(+47.1 \%)$ and $2008(+48.2 \%)$ (Fig. 2; Table S1). There was a significant interaction between water addition and sampling date in each year, with the strongest effects observed in August (2007) and July (2008) (Fig. 2). Nitrogen addition did not affect aboveground biomass in 2007 (Tables 1 and 2). In contrast, in $2008 \mathrm{~N}$ addition significantly increased aboveground biomass production $(+11.6 \%$, Table 1$)$; however, the $\mathrm{N}$ effect depended on the water treatment and varied with the season, as indicated by the significant $\mathrm{N} \times$ water $\times$ sampling date interaction (Table 1). A main effect of $\mathrm{N}$ addition on aboveground biomass was found in July $(+21.0 \%) 2008$, while significant $\mathrm{N} \times$ water interaction effects were found in August and September in 2008 (Fig. 2; Table 2).

\subsection{Fine root biomass}

Live fine root biomass was also stimulated by water addition both in 2007 and in 2008 (Table 1). Averaged across the four sampling dates, effects of water addition on live fine root biomass were stronger in $2008(+41.0 \%)$ than in $2007(+28.8 \%)$ as indicated by the significant water $\times$ year interaction (Table 1, Table S1; Fig. 3). In 2007, effects of water addition on live fine root biomass were strongest in

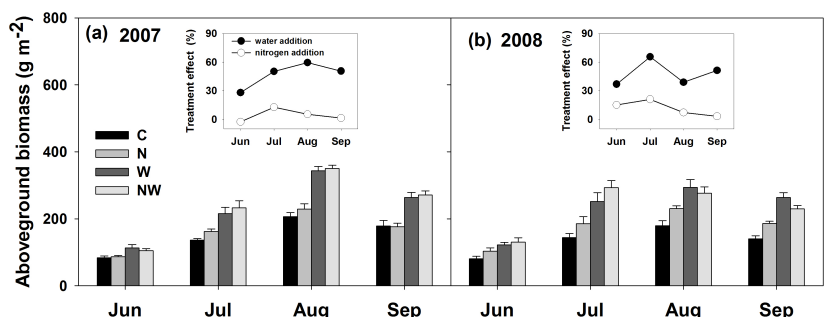

Fig. 2. Responses of aboveground biomass to water addition and nitrogen addition during the growing season in 2007 (a) and 2008 (b). Main effects of each treatment are shown in the insets. Data are presented as mean $\pm \operatorname{SE}(n=5)$. Treatments are as follows: $\mathrm{C}$ for control, $\mathrm{N}$ for nitrogen addition, $\mathrm{W}$ for water addition, and $\mathrm{NW}$ for nitrogen + water addition.

Table 1. $P$ values of repeated measures ANOVA testing for effects of nitrogen (N) and water addition (W), and sampling date (D) on aboveground biomass (AB), and live fine root biomass (LFRB) for 2007 and 2008. Significant effects $(P<0.05)$ are indicated in bold.

\begin{tabular}{llllll}
\hline & \multicolumn{2}{c}{$\mathrm{AB}$} & & \multicolumn{2}{c}{ LFRB } \\
\cline { 2 - 3 } \cline { 5 - 6 } & 2007 & 2008 & & 2007 & 2008 \\
\hline $\mathrm{N}$ & 0.22 & $<\mathbf{0 . 0 1}$ & & 0.15 & 0.62 \\
$\mathrm{~W}$ & $<\mathbf{0 . 0 0 1}$ & $<\mathbf{0 . 0 0 1}$ & & $<\mathbf{0 . 0 0 1}$ & $<\mathbf{0 . 0 0 1}$ \\
$\mathrm{N} \times \mathrm{W}$ & 0.65 & $<\mathbf{0 . 0 1}$ & & 0.96 & 0.62 \\
$\mathrm{D}$ & $<\mathbf{0 . 0 0 1}$ & $<\mathbf{0 . 0 0 1}$ & & $<\mathbf{0 . 0 0 1}$ & $<\mathbf{0 . 0 0 1}$ \\
$\mathrm{D} \times \mathrm{N}$ & 0.35 & 0.24 & & 0.07 & 0.89 \\
$\mathrm{D} \times \mathrm{W}$ & $<\mathbf{0 . 0 0 1}$ & $\mathbf{0 . 0 1}$ & & $\mathbf{0 . 0 0 1}$ & 0.68 \\
$\mathrm{D} \times \mathrm{N} \times \mathrm{W}$ & 0.82 & $<\mathbf{0 . 0 1}$ & & 0.17 & 0.79 \\
$\mathrm{Block}$ & 0.13 & $\mathbf{0 . 0 1}$ & & 0.66 & 0.63 \\
\hline
\end{tabular}

August $2007(+51.8 \%)$, as indicated by the significant water $\times$ sampling date interaction (Table 1). In 2008, effects of water addition on live fine root biomass gradually declined from June to September (Fig. 3). N addition had little effect on live fine root biomass; only in August 2007 there was a significant positive effect $(+19.6 \%)$ (Table 3; Fig. 3).

\subsection{Across-treatment correlations between plant biomass and soil nutrient and water content}

Except for June and July 2007, and August 2008, aboveground biomass was positively correlated with soil water content (Table 4). Aboveground biomass correlated positively with soil inorganic $\mathrm{N}$ concentrations for all sampling dates in 2008, but not in 2007 (Table 4). Live fine root biomass was correlated positively with soil moisture only in August and September 2007, and in July 2008 (Table 4). Live fine root biomass correlated positively with soil inorganic $\mathrm{N}$ only in August and September 2008 (Table 4). 
Table 2. Results from two-way ANOVA testing effects of nitrogen (N) and water addition (W) on aboveground plant biomass in 2007 and 2008. Significant effects $(P<0.05)$ are indicated in bold.

\begin{tabular}{|c|c|c|c|c|c|c|c|}
\hline \multirow[b]{2}{*}{$\begin{array}{l}\text { Sampling } \\
\text { date }\end{array}$} & \multirow[b]{2}{*}{ Effect } & \multicolumn{3}{|c|}{2007} & \multicolumn{3}{|c|}{2008} \\
\hline & & df & $F$ & $P$ & $\mathrm{df}$ & $F$ & $P$ \\
\hline \multirow[t]{4}{*}{ June } & $\mathrm{N}$ & 1 & 0.23 & 0.64 & 1 & 2.64 & 0.13 \\
\hline & $\mathrm{W}$ & 1 & 18.38 & $<0.001$ & 1 & 13.08 & $<0.01$ \\
\hline & $\mathrm{N} \times \mathrm{W}$ & 1 & 1.16 & 0.30 & 1 & 0.62 & 0.45 \\
\hline & Block & 4 & 2.45 & 0.10 & 4 & 1.18 & 0.37 \\
\hline \multirow[t]{4}{*}{ July } & $\mathrm{N}$ & 1 & 2.11 & 0.17 & 1 & 7.08 & 0.02 \\
\hline & $\mathrm{W}$ & 1 & 24.33 & $<0.001$ & 1 & 48.06 & $<0.001$ \\
\hline & $\mathrm{N} \times \mathrm{W}$ & 1 & 0.08 & 0.79 & 1 & 0.00 & 0.99 \\
\hline & Block & 4 & 0.82 & 0.54 & 4 & 3.95 & 0.03 \\
\hline \multirow[t]{4}{*}{ August } & $\mathrm{N}$ & 1 & 1.15 & 0.31 & 1 & 1.64 & 0.22 \\
\hline & $\mathrm{W}$ & 1 & 93.29 & $<0.001$ & 1 & 36.42 & $<0.001$ \\
\hline & $\mathrm{N} \times \mathrm{W}$ & 1 & 0.37 & 0.56 & 1 & 6.72 & 0.02 \\
\hline & Block & 4 & 0.88 & 0.50 & 4 & 3.90 & 0.03 \\
\hline \multirow[t]{4}{*}{ September } & $\mathrm{N}$ & 1 & 0.09 & 0.78 & 1 & 0.53 & 0.48 \\
\hline & $\mathrm{W}$ & 1 & 86.21 & $<0.001$ & 1 & 90.14 & $<0.001$ \\
\hline & $\mathrm{N} \times \mathrm{W}$ & 1 & 0.28 & 0.61 & 1 & 20.58 & 0.001 \\
\hline & Block & 4 & 5.36 & 0.01 & 4 & 2.58 & 0.09 \\
\hline
\end{tabular}

Table 3. Results from two-way ANOVA testing effects of nitrogen (N) and water addition (W) on live fine root biomass in 2007 and 2008. Significant effects $(P<0.05)$ are indicated in bold.

\begin{tabular}{|c|c|c|c|c|c|c|c|}
\hline \multirow[b]{2}{*}{$\begin{array}{l}\text { Sampling } \\
\text { date }\end{array}$} & \multirow[b]{2}{*}{ Effect } & \multicolumn{3}{|c|}{2007} & \multicolumn{3}{|c|}{2008} \\
\hline & & df & $F$ & $P$ & df & $F$ & $P$ \\
\hline \multirow[t]{4}{*}{ June } & $\mathrm{N}$ & 1 & 0.06 & 0.81 & 1 & 0.08 & 0.78 \\
\hline & $\mathrm{W}$ & 1 & 0.53 & 0.48 & 1 & 14.71 & $<0.01$ \\
\hline & $\mathrm{N} \times \mathrm{W}$ & 1 & 2.09 & 0.17 & 1 & 0.01 & 0.92 \\
\hline & Block & 4 & 3.27 & 0.05 & 4 & 0.21 & 0.93 \\
\hline \multirow[t]{4}{*}{ July } & $\mathrm{N}$ & 1 & 0.34 & 0.57 & 1 & 0.52 & 0.48 \\
\hline & $\mathrm{W}$ & 1 & 25.81 & $<\mathbf{0 . 0 0 1}$ & 1 & 20.41 & 0.001 \\
\hline & $\mathrm{N} \times \mathrm{W}$ & 1 & 0.03 & 0.87 & 1 & 1.14 & 0.31 \\
\hline & Block & 4 & 9.30 & 0.001 & 4 & 1.41 & 0.29 \\
\hline \multirow[t]{4}{*}{ August } & $\mathrm{N}$ & 1 & 4.84 & $<0.05$ & 1 & 0.16 & 0.70 \\
\hline & $\mathrm{W}$ & 1 & 25.72 & $<0.001$ & 1 & 12.73 & $<0.01$ \\
\hline & $\mathrm{N} \times \mathrm{W}$ & 1 & 0.13 & 0.72 & 1 & $<0.001$ & 0.98 \\
\hline & Block & 4 & 0.03 & 1.00 & 4 & 0.79 & 0.55 \\
\hline \multirow[t]{4}{*}{ September } & $\mathrm{N}$ & 1 & 1.16 & 0.30 & 1 & 0.10 & 0.76 \\
\hline & $\mathrm{W}$ & 1 & 19.38 & 0.001 & 1 & 10.65 & $<0.01$ \\
\hline & $\mathrm{N} \times \mathrm{W}$ & 1 & 2.95 & 0.11 & 1 & $<0.001$ & 0.99 \\
\hline & Block & 4 & 4.20 & 0.02 & 4 & 0.58 & 0.68 \\
\hline
\end{tabular}

\subsection{Rainfall and nitrogen use efficiency}

In 2007, aboveground biomass increased linearly with accumulated precipitation (Fig. 4). In 2008, however, the relationship between aboveground biomass and accumulated precipitation was best described by a quadratic polynomial regression: the slope of the relationship started to decrease when accumulated precipitation was about $190 \mathrm{~mm}$ (Fig. 4).
A similar pattern was found for the relationship between root $\mathrm{N}$ uptake and accumulated precipitation (Fig. S1). Both in 2007 and 2008, live fine root biomass increased linearly with accumulated precipitation, and the rate with which live fine root biomass increased did not differ between the two years ( $P=0.10$ in slope comparison by SMA) (Fig. 5). NUE, measured as the slope of the regression between root $\mathrm{N}$ uptake and aboveground biomass production, did not differ between 
Table 4. Correlation coefficients for plant biomass and soil water and nutrient content in 2007 and 2008 . $^{*}$, ** and *** indicate significant level at $P<0.05, P<0.01$, and $P<0.001$, respectively; ns is non-significant. Abbreviations: AB for aboveground biomass, LFRB for live fine root biomass, SWC for soil water content, and SIN for soil inorganic N content.

\begin{tabular}{llllll}
\hline Year & $\begin{array}{l}\text { Sampling } \\
\text { data }\end{array}$ & AB-SWC & AB-SIN & LFRB-SWC & LFRB-SIN \\
\hline 2007 & June & $0.28 \mathrm{~ns}$ & $-0.05 \mathrm{~ns}$ & $0.35 \mathrm{~ns}$ & $-.030 \mathrm{~ns}$ \\
& July & $0.41 \mathrm{~ns}$ & $0.20 \mathrm{~ns}$ & $0.26 \mathrm{~ns}$ & $-0.04 \mathrm{~ns}$ \\
& August & $0.81^{* * *}$ & $-0.002 \mathrm{~ns}$ & $0.649^{* *}$ & $0.18 \mathrm{~ns}$ \\
& September & $0.81^{* * *}$ & $0.36 \mathrm{~ns}$ & $0.59^{* *}$ & $0.43 \mathrm{~ns}$ \\
2008 & June & $0.58^{* *}$ & $0.52^{*}$ & $0.39 \mathrm{~ns}$ & $0.23 \mathrm{~ns}$ \\
& July & $0.61^{* *}$ & $0.60^{* *}$ & $0.54^{*}$ & $0.23 \mathrm{~ns}$ \\
& August & $0.51 \mathrm{~ns}$ & $0.55^{*}$ & $0.10 \mathrm{~ns}$ & $0.53^{*}$ \\
& September & $0.76^{* * *}$ & $0.77^{* * *}$ & $0.41 \mathrm{~ns}$ & $0.75^{* * *}$ \\
\hline
\end{tabular}

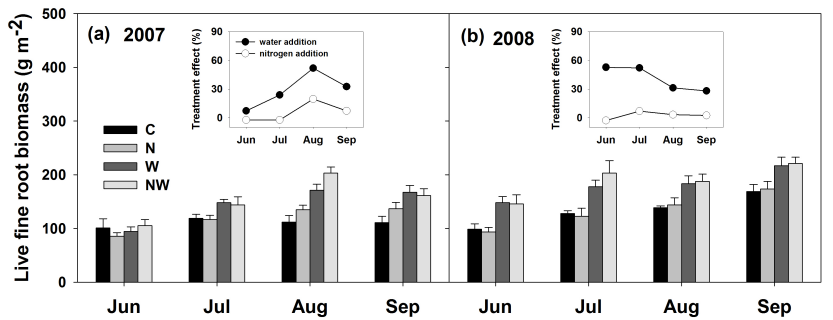

Fig. 3. Responses of live fine root biomass to water addition and nitrogen addition during the growing season in 2007 (a) and 2008 (b). Main effects of each treatment are shown in the insets. Data are presented as mean $\pm \mathrm{SE}(n=5)$. $\mathrm{C}$ is for control, $\mathrm{N}$ for nitrogen addition, $\mathrm{W}$ for water addition, and NW for nitrogen + water addition.

2007 and 2008 ( $P=0.66$ in slope comparison by SMA) (Fig. 6).

\section{Discussion}

We found significant effects of water addition on aboveground and fine root biomass, consistent with the view that water availability is a predominant factor driving plant growth and productivity in semiarid grasslands (Hooper and Johnson, 1999; Maestre and Reynolds 2007; Kardol et al., 2010). Although the overall stimulation of plant biomass by water addition was consistent between the two years of study, we showed contrasting seasonality. For the dry year (2007), effects of water addition on plant biomass peaked in August, whereas for the wet year (2008), effects of water addition strongly declined from July to August. The decline of water addition effects concurred with the occurrence of an extreme rainfall event (Fig. 1c), providing support for our first hypothesis that extreme rainfall events negatively affect plant responses to water addition.

The inter-annual variation in effects of water addition on plant biomass as observed in our study may be related to shifts in rainfall use efficiency (RUE) with increasing accu-

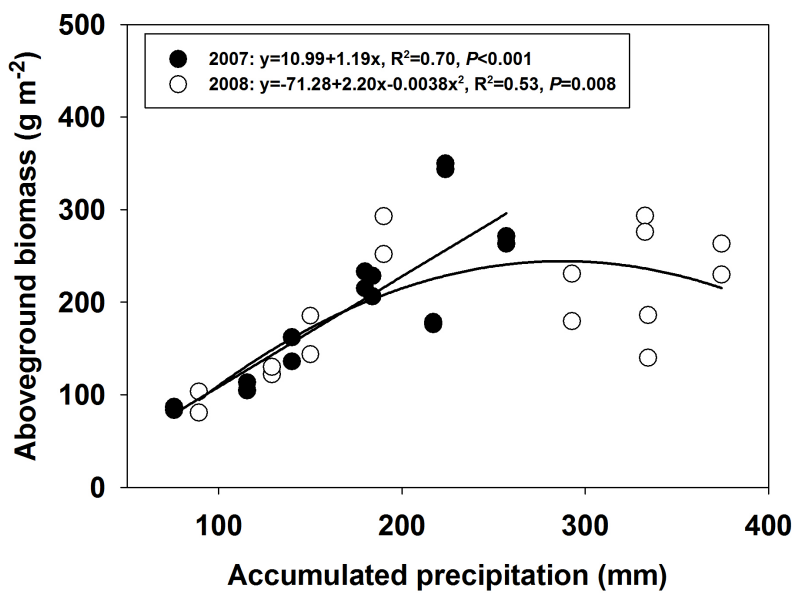

Fig. 4. The relationship between aboveground biomass and accumulated precipitation in 2007 (solid circles) and 2008 (open circles).

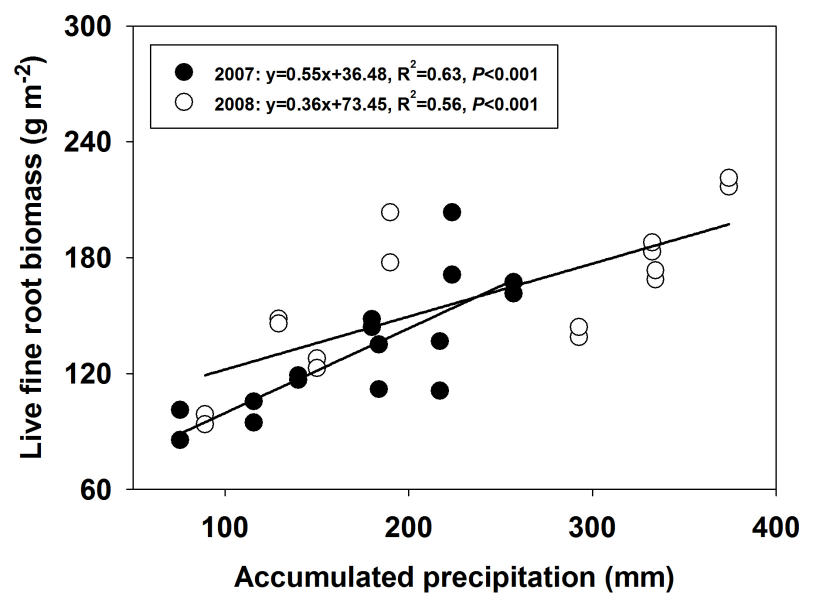

Fig. 5. The relationship between live fine root biomass and accumulated precipitation in 2007 (solid circles) and 2008 (open circles).

mulated precipitation. In 2007, the RUE was constant, while there was a remarkable decline of the RUE in 2008 when 


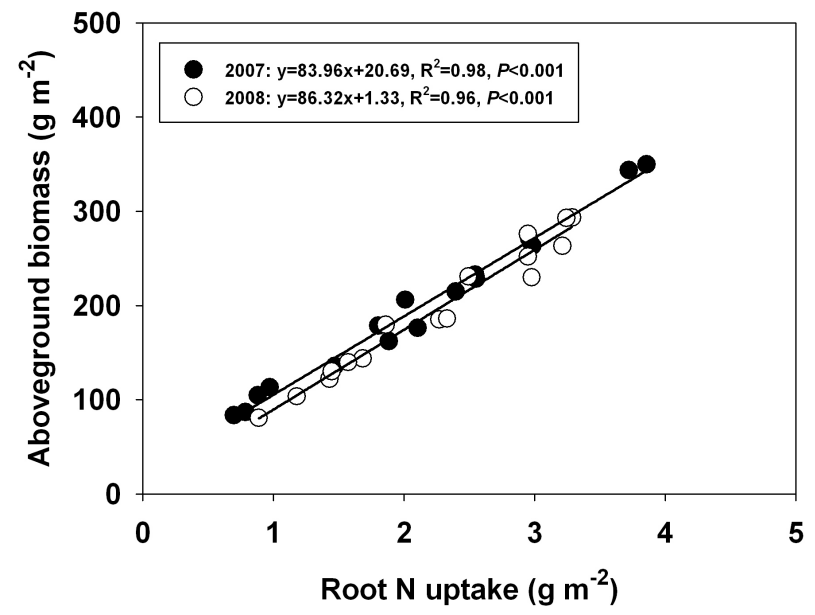

Fig. 6. The relationship between root $\mathrm{N}$ uptake and aboveground biomass in 2007 (solid circles) and 2008 (open circles).

accumulated precipitation exceeded the 2007 value (Fig. 4). This finding suggests a threshold of water supply for plant growth above which additional water can no longer be efficiently used. The threshold value observed in our study (including both ambient and added precipitation) is much lower than values previously reported for temperate grasslands (e.g., Paruelo et al., 1999; Huxman et al., 2004a; Bai et al., 2008; Hsu et al., 2012). The seasonal decline of RUE in 2008 probably can be attributed to changes in precipitation regime other than the total amount of precipitation (i.e., the occurrence of a $63 \mathrm{~mm}$ rainfall event between the July and August sampling dates). Such extreme rainfall events can result in surface runoff or leaching (Elrashidi et al., 2005; Li et al., 2007; Zhou et al., 2008), as was observed in our study (D. L. Kong, personal observation, 2008). Water and nutrient loss through runoff or leaching can lead to a lower threshold value of water supply above which RUE will decline.

However, reduced RUE resulting from runoff after an extreme rainfall cannot explain the decrease of plant biomass responses to our water addition treatment. A large portion of water input by an extreme rainfall event is lost rather than used to attenuate water limitation, and, hence, effects of water addition in this case should not be affected. Detailed analysis of our data indicated that the decline of effect of water addition during the 2008 growing season could be largely attributed to reduced stimulation of aboveground biomass by water addition when combined with $\mathrm{N}$ addition. This could be demonstrated by the fact that aboveground biomass in August 2008 was $19.7 \%$ higher in $\mathrm{N}+$ water treatments than in N-only treatments ( $t$ test: $P>0.05$ ), while aboveground biomass was $63.6 \%$ higher in water-only treatments (W) than in control treatments (C) $(t$ test: $P<0.01$, Fig. 2 b). In $\mathrm{N}+$ water treatments, more than in $\mathrm{N}$-only treatments, soil inorganic $\mathrm{N}$ may have been available mainly as $\mathrm{NO}_{3}^{-}-\mathrm{N}$ because of greater activity of nitrifying soil microbes under wet conditions (Wang et al., 2006; Liu et al., 2009). Therefore, soil available $\mathrm{N}$ in $\mathrm{N}+$ water plots could have been more negatively affected by the extreme rainfall event as mobile $\mathrm{NO}_{3}^{-}-\mathrm{N}$ can easily be lost in runoff and leaching. As such, in a previous study, Lü et al. (2011) found a greater loss of soil $\mathrm{NO}_{3}^{-}-\mathrm{N}$ in $\mathrm{N}+$ water treatments than in $\mathrm{N}$-only treatments. Additionally, the negative effects of extreme rainfall events on soil available $\mathrm{N}$ may result in plant growth being $\mathrm{N}$-limited rather than water-limited and, hence, explain the significant correlations of both aboveground and fine root biomass with soil inorganic $\mathrm{N}$ but not for soil water content in August of 2008 (Table 4). Given that the rate of root N uptake began to decline just after the occurrence of an extreme rainfall event in 2008, negative effects of extreme rainfall events could also have resulted from shifts in root $\mathrm{N}$ uptake (Lü et al., 2011). Taken together, our results suggest that reduced plant biomass responses to water addition in 2008 resulted from negative effects of an extreme rainfall event on RUE through nutrient loss rather than through water loss.

Our results differ from previous studies stressing the importance of extreme rainfall events in altering soil moisture variability (Knapp et al., 2002) or soil water content (Huxman et al., 2004b; Chen et al., 2009) and, hence, suppressing plant productivity. The discrepancies among studies may be related to the different consequences an extreme rainfall event can have depending on external factors. For example, surface runoff occurs more likely and more strongly in ecosystems with low vegetation coverage (Bai et al., 2008; Knapp et al., 2008) and in systems with high mean annual precipitation (Knapp et al., 2001; Huxman et al., 2004a). Results of our study support the idea that negative effects of extreme rainfall events on soil $\mathrm{N}$, but not water availability (and hence on RUE), can drive inter-annual and seasonal variation in plant biomass response to water addition. Considering the global increases in $\mathrm{N}$ deposition (Galloway et al., 2008) and projected greater precipitation variability under future climate scenarios, our study suggests that effects of $\mathrm{N}$ deposition on plant growth and ecosystem processes can be suppressed in the case of an extreme rainfall event.

The inter-annual fluctuation in precipitation caused by an extreme rainfall event can also affect plant biomass response to $\mathrm{N}$ addition. In 2007 , there was no response of aboveground biomass to $\mathrm{N}$ addition, while in 2008 plant biomass responded positively. The significant effect of $\mathrm{N}$ addition in 2008 was found for the sampling dates before an extreme rainfall event (July), but not thereafter. The neutral effect of $\mathrm{N}$ addition in August 2008 was due to suppressed stimulation of plant biomass in responses to $\mathrm{N}$ addition when combined with water addition $(-5.9 \%, \mathrm{NW}$ vs. W treatments; $t$ test: $P>0.05)$ compared to $\mathrm{N}$ addition only $(+28.6 \%, \mathrm{~N}$ vs. C treatments; $t$ test: $P<0.05$ ) (Fig. 2). The findings thus support our second hypothesis that plant biomass responses to $\mathrm{N}$ addition can be reduced by the occurrence of extreme rainfall events, as well as our third hypothesis for negative effects of extreme rainfall on the interaction effects between 
water and $\mathrm{N}$ addition. As for fine root response to $\mathrm{N}$ addition, it is interesting to note that in August 2008 there was no stimulation of fine root biomass production in response to $\mathrm{N}$ addition alone ( $P>0.05$ in $t$ test, Fig. $3 \mathrm{~b}$ ), while aboveground biomass was positively affected by $\mathrm{N}$ addition at this sampling date $(P<0.05$ in $t$ test, Fig. $2 \mathrm{~b})$. Given that $\mathrm{NO}_{3}^{-}$$\mathrm{N}$ might leach from the soil more easily than $\mathrm{NH}_{4}^{+}-\mathrm{N}$ after the extreme rainfall event, a possible explanation for the contrasting aboveground and belowground responses is that plants in $\mathrm{N}$-only plots may depend mainly on $\mathrm{NH}_{4}^{+}-\mathrm{N}$ for aboveground biomass production. This could be achieved by increasing root surface area rather than root biomass (Norby et al., 2004); however, this idea requires further study.

Negative effects of extreme rainfall events on soil available $\mathrm{N}$ can result in a decrease of fertilizer use efficiency, i.e., the ratio of aboveground net primary production to the amount of added N (Hooper and Johnson, 1999). However, for each unit of absorbed N, we found similar plant NUE for the two years of study as indicated by the very similar slopes of the regression between root $\mathrm{N}$ uptake and aboveground biomass (Fig. 6). Plant NUE generally increases with increasing precipitation because of enhanced stomatal conductance and photosynthetic efficiency under conditions of higher water availability (Patterson et al., 1997; Zhang and Cao, 2009). We suggest that the lack of increase in NUE in the wet year 2008 relative to the dry year 2007 could have resulted from water being lost from the ecosystem after the extreme rainfall event instead of being absorbed by the plants to increase NUE.

In summary, our study shows that inter-annual precipitation fluctuations resulting from the emergence of an extreme rainfall event could have the potential to modify plant response to water and $\mathrm{N}$ enrichment. These effects were achieved through the negative influence of extreme rainfall on soil $\mathrm{N}$ and water availability ultimately reducing ecosystem RUE and NUE. Climate models predict higher variation of inter-annual precipitation with more frequent extreme rainfall events under future climate conditions (Easterling et al., 2000; Weltzin et al., 2003; Zhang et al., 2007; Knapp et al., 2008; Min et al., 2012). The influence of shifts in precipitation regime can be particularly important in semiarid grasslands as water availability is the predominant factor impacting on a range of key ecosystem processes (Weltzin et al., 2003; Nippert et al., 2006; Knapp et al., 2008). On the other hand, it should be noted that there was only one extreme rainfall event in the middle growing season that caused negative effects on the added $\mathrm{N}$ through runoff or leaching and hence plant growth in this period. These effects may be different if the timing and frequency of extreme rainfall events changed (Knapp et al., 2008; Robinson et al., 2013). Although these issues should be stressed in future studies, the striking effect of an extreme rainfall event on plant response to water and $\mathrm{N}$ enrichment as observed here suggests the importance of integrating extreme rainfall events in ecological models to enhance the predictive power for ecosystem responses under multiple global environmental changes (Dukes et al., 2005; Bradford et al., 2012; Kardol et al., 2012).

\section{Supplementary material related to this article is available online at http://www.biogeosciences.net/10/ 8129/2013/bg-10-8129-2013-supplement.pdf.}

Acknowledgements. We thank Dezhu Kong, Weijun Wu, Yongsheng Jin, Qiang Li, and Shuxia Liu for their help with the fieldwork and laboratory work. We are also grateful for Prof. Shiqiang Wan, Zhongling Yang and Dr. Junjian Wang for their valuable comments on earlier versions of the manuscript. Great thanks are also given to two anonymous reviewers and the editor, Dr. Fiona Carswell, for their valuable comments and careful revision in improving this manuscript. This study was supported by National Natural Science Foundation of China (nos. 31200344, 41273094, 31021001 and 31000232).

Edited by: F. Carswell

\section{References}

Austin, A. T., Yahdjian, L., Stark, J. M., Belnap, J., Porporato, A., Norton, U., Ravetta, D. A., and Schaeffer, S. M.: Water pulses and biogeochemical cycles in arid and semiarid ecosystems, Oecologia, 141, 221-235, 2004.

Bai, Y., Han, X., Wu, J., Chen, Z., and Li, L.: Ecosystem stability and compensatory effects in the Inner Mongolia grassland, Nature, 431, 181-184, 2004

Bai, Y., Wu, J., Xing, Q., Pan, Q., Huang, J., Yang, D. L., and Han, X. G.: Primary production and rain use efficiency across a precipitation gradient on the Mongolia Plateau, Ecology, 89, 21402153, 2008.

Bradford, M. A., Wood, S. A., Maestre, F. T., Reynolds, J. F., and Warren II, R. J.: Contingency in ecosystem but not plant community response to multiple global change factors, New Phytol., 196, 462-471, 2012.

Chapin, F. S, Matson, P. A., and Mooney, H. A.: Principles of Terrestrial Ecosystem Ecology. Springer-Verlag, New York, USA, 2002.

Chen, S. P., Lin, G. H., Huang, J. H., and Jenerettew, G. D.: Dependence of carbon sequestration on the differential responses of ecosystem photosynthesis and respiration to rain pulses in a semiarid steppe, Glob. Change Biol., 15, 2450-2461, 2009.

Chen, Z. Z. and Wang, S. P.: Typical steppe ecosystems of China (in Chinese), Science, Beijing, 2000.

Craine, J. M., Nippert, J. B., Elmore, A. J., Skibbe, A. M., Hutchinson, S. L., and Brunsell, N. A.: Timing of climate variability and grassland productivity, P. Natl. Acad. Sci. USA, 109, 3401-3405, 2012.

Dukes, J. S., Chiariello, N. R., Cleland, E. E., Moore, L. A., Shaw, M. R., Thayer, S., Tobeck, T., Mooney, H. A., and Field, C. B.: Responses of grassland production to single and multiple global environmental changes, Plos Biol., 10, 1829-1837, 2005. 
Easterling, D. R., Meehl, G. A., Parmesan, C., Changnon, S. A., Karl, T. R., and Mearns, L. O.: Climate extremes, Observations, modeling, and impacts, Science, 289, 2068-2074, 2000.

Elrashidi, M. A., Mays, M. D., Fares, A., Seybold, C. A., Harder, J.L., Peaslee, S. D., and Van Neste, P.: Loss of nitrate-nitrogen by runoff and leaching for agricultural watersheds, Soil Sci., 170, 969-984, 2005.

Falster, D. S., Warton, D. I., and Wright, I. J.: SMATR, standardised major axis tests and routines, ver 2.0. [WWW document], http:// www.bio.mq.edu.au/ecology/SMATR (last access: 22 November 2006), 2006.

Fay, P. A., Kaufman, D. M., Nippert, J. B., Carlisle, J. D., and Harper, C. W.: Changes in grassland ecosystem function due to extreme rainfall events, implications for responses to climate change, Glob. Change Biol., 14, 1600-1608, 2008.

Galloway, J. N., Townsend, A. R., Erisman, J. W., Bekunda, M., Cai, Z. C., Freney, J. R., Martinelli, L. A., Seizinger, S. P., and Sutton, M. A.: Transformation of the nitrogen cycle, recent trends, questions, and potential solutions, Science, 320, 889-892, 2008.

Hooper, D. and Johnson, L.: Nitrogen limitation in dryland ecosystems, responses to geographical and temporal variation in precipitation, Biogeochemistry, 46, 247-293, 1999.

Hsu, J. S., Powell, J., and Adler, P. B.: Sensitity of mean annual primary production to precipitation, Global Change Biol., 18, 22462255, 2012.

Huntington, T. G.: Evidence for intensification of the global water cycle, Review and synthesis, J. Hydrol., 319 83-95, 2006.

Huxman, T. E., Smith, M. D., Fay. P. A., Knapp, A. K., and Shaw, M. R.: Convergence across biomas to a common rain-use efficiency, Nature, 429, 651-654, 2004a.

Huxman, T. E., Snyder, K. A., Tissue, D., Leffler, A. J., Ogle, K., Pockman, W. T., Sandquist, D. R., Potts, D. L., and Schwinning S.: Precipitation pulses and carbon flux in semiarid and arid ecosystems, Oecologia, 141, 254-268, 2004b.

Kardol, P., Campany, C. E., Norby, R. J., Weltzin, J. F., and Classen, A. T.: Climate change effects on plant biomass alter dominance patterns and community evenness in an experimental old-field ecosystem, Glob. Change Biol., 16, 2676-2687, 2010.

Kardol, P., De Long, J. R., and Sundqvist, M. K.: Crossing the threshold, the power of multi-level experiments in identifying global change responses, New Phytol., 196, 323-326, 2012.

Kin, S. K., Zhang, X. B., Zwiers, F. W., and Hegerl, G. C.: Human contribution to more-intense precipitation extremes, Nature, 470, 378-381, 2012.

Knapp, A. K. and Smith, M. D.: Variation among biomes in temporal dynamics of aboveground primary production, Science, 291, 481-484, 2001

Knapp, A. K., Fay, P. A., Blair, J. M., Collins, S. L., Smith, M. D., Carlisle, J. D., Harper, C. W., Danner, B. T., Lett, M. S., and McCarron, J. M.:: Rainfall variability, carbon cycling and plant species diversity in a mesic grassland, Science, 298, 2202-2205, 2002.

Knapp, A. K., , Beier, C., Briske, D. D., Classen, A.T., Luo, Y., Reichstein, M., Smith, M. D., Smith, S. D., Bell, J. E., Fay, P. A., Heisler, J. L., Leavitt, S. W., Sherry, R., Smith, B., and Weng, E.: Consequences of more extreme precipitation regimes for terrestrial ecosystems, Bioscience, 58, 811-821, 2008.

Kong, D. L., Wu, H. F., Wang, M., Matthew, S., Lü, X. T., Yu, Q., and Han, X. G.: Structural and chemical differences between shoot- and root-derived roots of three perennial grasses in a typical steppe in Inner Mongolia China, Plant Soil, 336, 209-217, 2010.

Kong, D. L., Wu, H. F., Zeng, H., Lü, X. T., Matthew, S., Wang, M., Sun, X. F., and Han X. G.: Plant functional group removal alters root biomass and nutrient cycling in a typical steppe in Inner Mongolia, China, Plant Soil, 346, 133-144, 2011.

LeBauer, D. S. and Treseder, K. K.: Nitrogen limitation of net primary productivity in terrestrial ecosystems is globally distributed, Ecology, 89, 371-379, 2008.

Li, J., Okin, G. S., Alvarez, L., and Epstein, H.: Quantitative effects of vegetation cover on wind erosion and soil nutrient loss in a desert grassland of southern New Mexico, USA, Biogeochemistry, 85, 317-332, 2007.

Liu, W., Zhang, Z., and Wan, S.: Predominant role of water in regulating soil and microbial respiration and their responses to climate change in a semiarid grassland, Glob. Change Biol., 15, 184-195, 2009.

Lü, F. M., Lü, X. T., Liu, W., Han, X., Zhang, G. M., Kong, D. L., and Han, X. G.: Carbon and nitrogen storage in plant and soil as related to nitrogen and water amendment in a temperate steppe of northern China, Biol. Fert. Soils, 47, 187-196, 2011.

Maestre, F. T. and Reynolds, J. F.: Amount or pattern? Grassland responses to the heterogeneity and availability of two key resources, Ecology, 88, 501-511, 2007.

Neatrour, M. A., Jones. R. H., and Golladay, S. W.: Correlations between soil nutrient availability and fine-root biomass at two spatial scales in forested wetlands with contrasting hydrological regimes, Can. J. Forest Res., 35, 2934-2941, 2005.

Nippert, J. B., Knapp, A. K., and Briggs, J. M.: Intra-annual rainfall variability and grassland productivity, can the past predict the future?, Plant Ecol., 184, 65-74, 2006.

Norby, R. J., Ledford, J., Reilly, C. D., Miller, N. E., and O’Neill, E. G.: Fine-root production dominates response of a deciduous forest to atmospheric $\mathrm{CO}_{2}$ enrichment, P. Natl. Acad. Sci. USA, 101, 9689-9693, 2004.

Paruelo, J. M., Ledford, J., Reilly, C. D., Miller, N. E., and O’Neil, E. G.: Grassland precipitation-use efficiency varies across a resource gradient, Ecosystems, 2, 64-68, 1999.

Patterson, T. B., Guy, R. D., and Dang, Q. L.: Whole-plant nitrogenand water-relations traits, and their associated trade-offs, in adjacent muskeg and upland boreal spruce species, Oecologia, 110, 160-168, 1997.

Robinson, T. M. P., La Pierre, K. J., Vadeboncoeur, M. A., Byrne, K. M., Thomey, M. L., and Colby, S. E.: Seasonal, not annual precipitation drives community productivity across ecosystem, Oikos, 122, 727-738, 2013.

Wang, C. H., Wan, S. Q., Xing, X. R., Zhang L., and Han, X. G.: Temperature and soil moisture interactively affected soil net $\mathrm{N}$ mineralization in temperate grassland in Northern China, Soil Biol. Biochem., 38, 1101-1110, 2006.

Weltzin, J. F., Loik, M. E., Schwinning, S., Williams, D. G., Fay, P. A., Haddad, B. M., Harte, J., Huxman, T. E., Knapp, A. K., Lin, G., Pockman, W. T., Shaw, M. R., Small, E. E., Smith, M. D., Smith, S. D., Tissue, D. T., and Zak, J. C.: Accessing the response of terrestrial ecosystems to potential changes in precipitation, Bioscience, 53, 941-952, 2003.

Wu, Z. T., Dijkstra, P., Koch, G.. W., Penuelas, J., and Hungate, B. A.: Responses of terrestrial ecosystems to temperature and pre- 
cipitation change, a meta-analysis of experimental manipulation, Glob. Change Biol., 17, 927-942, 2011.

Xia, J. Y. and Wan, S. Q.: Global response patterns of terrestrial plant species to nitrogen addition, New Phytol., 179, 428-439, 2008.

Xiao, C. W., Janssens, I. A., Liu, P., Zhou, Z. Y., and Sun, O. J.: Irrigation and enhanced soil carbon input effects on below-ground carbon cycling in semiarid temperate grasslands, New Phytol., 174, 835-846, 2007.

Yang, Y. H., Fang, J. Y., Ma, W. H., Guo, D. L., and Mohammat A.: Large-scale pattern of biomass partitioning across China's grasslands, Global Ecol. Biogeogr., 19, 268-277, 2010.
Zhang, J. L. and Cao, K. F.: Stem hydraulics mediates leaf water status, carbon gain, nutrient use efficiencies and plant growth rates across dipterocarp species, Funct. Ecol., 23, 658-667, 2009.

Zhang, X., Zwiers, F. W., Hegerl, G. C., Lambert, F. H., Gillett, N. P., Solomon, S., Stott, P. A., and Nozawa, T.: Detection of human influence on twentieth-century precipitation trends, Nature, 448, 461-465, 2007.

Zhou, X., Weng, E., and Luo, Y.: Modeling patterns of nonlinearity in ecosystem responses to temperature, $\mathrm{CO}_{2}$, and precipitation changes, Ecol. Appl., 18, 453-466, 2008. 